\title{
A Study on Multi-morbidity among Geriatric Group in a District of Northern India: A Cross Sectional Study
}

\author{
Vandana Verma ${ }^{1}$, Neha Mishra ${ }^{2, *}$
}

\begin{abstract}
Introduction: Demographic transition with ageing of the population is a global phenomenon which demands international, national, regional and local action. The percentage of the elderly population in India increased from 5.4 percent in 1950 to be about 8.7 percent in 2015 and expected to be 12.4 percent in 2030 and 19.6 percent in 2050 . Several forces are driving India's changing age structure, including an upward trend in life expectancy and falling fertility. The aging populations is a sign of successful development in medical sciences and technology, living standards and education, but also raise unique social, economic and clinical challenges, including a growing demand for increasingly complex healthcare service. Materials and Methods: This cross-sectional study was conducted period of one year (August 2014 to July 2015) in Allahabad districts on elderly population only. Data was collected by house to house visits. Informed consent was obtained. Morbidity was assessed by taking history, doing a clinical examination, reviewing past medical records (musculoskeletal disorders, hearing problems, eye problems, hypertension and diabetes) and medicines taken by the study subject. Chi-square test was used to find out associated with morbidity in elderly population. Results: We were found mean age of study participant was 68.86 years. Majority of subjects $(31.8 \%)$ were suffering from two chronic conditions, followed by $15.5 \%$ were having three chronic conditions, $4.8 \%$ having four chronic diseases and $1 \%$ were found to be suffering from five chronic diseases conditions. Conclusion: The preventive programme and strategies should be focused on more frequent and periodic screening of elderly with special focus to elderly female, Health education and health service provision near the dwelling place through mobile health team and by peripheral workers.

Key words: Elderly, Multi-morbidity, Life expectancy, Chronic Disease, Screening.
\end{abstract}

\section{Vandana Verma', Neha Mishra ${ }^{2, *}$ \\ 'Department of Community Medicine, Career Medical College, Lucknow, Uttar Pradesh, INDIA. \\ ${ }^{2}$ Department of Statistics, University of Lucknow, Lucknow, Uttar Pradesh, INDIA.}

\section{Correspondence}

Ms. Neha Mishra,

Research Scholor, Department of Statsitics, University of Lucknow, Lucknow-226007, Uttar Pradesh, INDIA. Mobile no: +919598741390

Email: nehamishra2605@gmail.com

History

- Submission Date: 22-08-2019;

- Revised Date: 04-10-2019;

- Accepted Date: 08-11-2019;

DOI : 10.5530/ijmedph.2019.4.29

Article Available online

http://www.ijmedph.org/v9/i4

\section{Copyright}

(C) 2019 Phcog.Net. This is an openaccess article distributed under the terms of the Creative Commons Attribution 4.0 International license.

\section{INTRODUCTION}

Population ageing is an inevitable and irreversible demographic reality that is associated with welcome improvements in health and medical care. At the moment, there is no United Nations standard numerical criterion, but the UN agreed cut off is $60+$ years to refer to the older population. ${ }^{1}$ Ageing population is defined as a shift of population age composition toward older age $\geq \mathrm{g} 60$ years as direct impact of decrease in fertility and increase in life expectancy. ${ }^{2}$ The elderly population $\geq \mathrm{h} 60$ years is growing every year, by the year 2025 the world will host 1.2 billion people, over and rising to 1.9 billion in $2050 .^{3}$ The health problems of elderly are influenced by many other factors such as social, economic and psychosocial interaction to a greater extent as compared to younger people. ${ }^{4}$ Over the next four decades, India's demographic structure is also expected to shift dramatically from a young to an aging population resulting in 316 million elderly persons by $2050 .^{5}$ The percentage of the elderly population in India increased from 5.4 percent in 1950 to 6.1 percent in 1990 and is expected to be about 8.7 percent in 2015, 11.1 percent in 2025, 12.4 percent in 2030 and 19.6 percent in $2050 .^{6}$ The successful ageing among the elderly has also shifted the spectrum of the diseases from communicable to non-communicable diseases, where these chronic diseases accumulate over the time and is presented as Multi-morbidity in the given set of population. ${ }^{7,8}$ Multi-morbidity is defined as any combination of chronic diseases with at least one other diseases (acute or chronic) or biopsychic social factors (associated or not) or somatic risk factors. WHO report states that Non-Communicable Disease's account for at least $32 \%$ of all deaths in India with a word of caution that this could be an 'under and inadequate estimation'. The impact should be higher in the geriatric population. ${ }^{9}$ The present study will throw some light on the prevalence of Multi-morbidity and the factors which are associated with it. Ethical clearance from the institutional ethics committee was obtained before conducting the study. Besides, informed consent was taken from each study participant.

\section{MATERIALS AND METHODS}

It was a cross sectional study which was carried out as a part of dissertation among the elderly aged $\geq 60$ years and above residing in Allahabad District. The study was done in randomly selected urban wards 
and Primary Health Centers (PHC) of Allahabad. Multi-stage random sampling was done. The urban wards of Allahabad city and total PHC's of Allahabad District were listed. In the First stage two wards from the urban area and two PHC's from rural area were selected randomly. The sample size of 400 was calculated from Research Adviser 2006 based on target population of 5,06,123 elderly in Allahabad district with $95 \%$ CI and $5 \%$ margin of error. The data was collected by house to house interview method after taking the informed consent and explaining the purpose of the study. The information was collected on a pretested, pre-designed, semi structure questionnaire, whereas the Multi-morbidity was assessed based on history, clinical examination, past medical records and any intake of medication at present. Validity of questionnaire was tested in pilot testing prior to the data collection. Chi square test was used to test any association between the different variables. Data was analysed on statistical software, SPSS 22.0 version. The $p$ value is less than 0.05 was considered to be significant.

\section{RESULTS}

The mean age of study participant was 68.86 years. The socio demographic data of study subject is given in Table 1 . Out of 400 participants $215(56.8 \%)$ were male and $185(46.3 \%)$ were female. Majority of study subject belonged to age group 60-65 years 253 (63.25\%), followed by 70 79 years, $107(26.75 \%)$ and only $40(10 \%)$ were $>80$ years. It was observed that $225(56.25 \%)$ were literate and 175 (43.75\%) were illiterate. Majority of them 300 (75\%) were currently married and 100 (25\%) were single or unmarried. As per B.G Prasad scale, around half of them 219 (54.75\%) belonged to Lower class, followed by 126 (31.5\%) to upper class and 55(13.75\%) were in middle socio-economic class.

A total of 212 study participants (53\%) were found to be suffering from two or more chronic diseases i.e., Multi-morbidity. Distribution of elderly according to number of medicals conditions is shown in (Figure $1)$. It can be seen that $(31.8 \%)$ were suffering from two chronic conditions, followed by $15.5 \%$ were having three chronic conditions, $4.8 \%$ having four chronic diseases and $1 \%$ were found to be suffering from five chronic diseases conditions. Table 2 depicts, the common chronic health conditions reported by gender among the elderly where the three most common diseases are anaemia (37.5\%), hypertension $(41.75 \%)$ and Arthritis (52.5\%). Whereas the prevalence of anaemia (48.6\%) and Arthritis (61\%) were reported more commonly among females which was also found to be significant. COPD (4.1\%) and Genitourinary (15.34\%) problems were more significantly common among the Males.

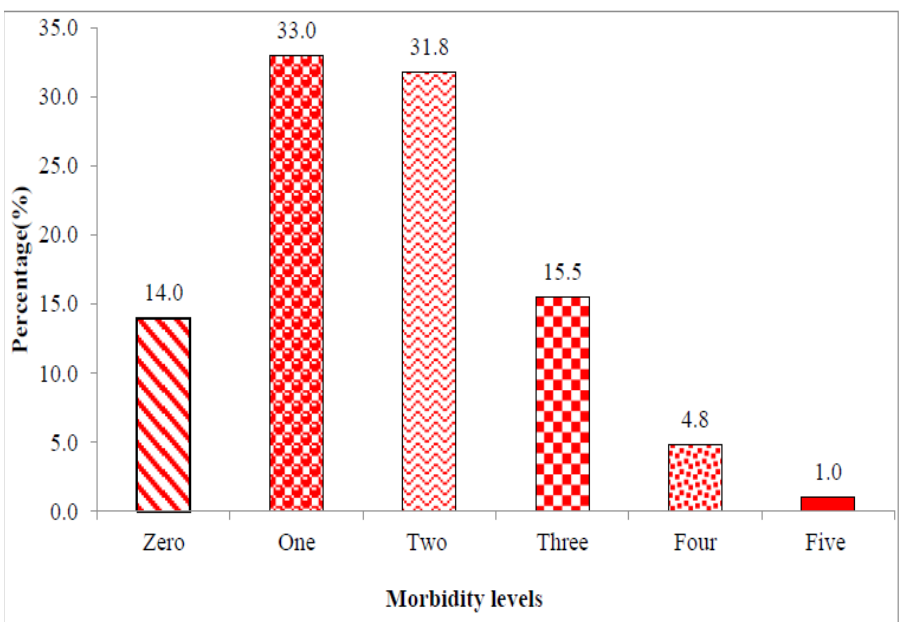

Figure 1 : Distribution of Multimorbidity levels of Study Participants.

\begin{tabular}{lc}
\begin{tabular}{l} 
Table 1: Socio-demographic variable of study population. \\
\multicolumn{1}{c}{ Socio-demographic Variables } \\
Gender
\end{tabular} \\
$\begin{array}{l}\text { Male } \\
\text { Female }\end{array}$ \\
Age -group (in Years) \\
$60-69$ \\
$70-79$ & $185(46.3)$ \\
$>80$ & $253(63.25)$ \\
Education Status & $107(26.75)$ \\
Illiterate & $40(10)$ \\
Literate & $175(43.75)$ \\
Marital Status & $225(56.25)$ \\
Single & \\
Married & $100(25)$ \\
Socio-economic Status & $300(75)$ \\
Upper & \\
Midle & $126(31.5)$ \\
Lower & $55(13.75)$ \\
\hline
\end{tabular}

\begin{tabular}{|c|c|c|c|c|}
\hline $\begin{array}{l}\text { Health } \\
\text { Condition }\end{array}$ & $\begin{array}{c}\mathrm{N} \\
(\%)\end{array}$ & $\begin{array}{l}\text { Male } \\
\mathrm{N}(\%)\end{array}$ & $\begin{array}{c}\text { Female } \\
\mathrm{N}(\%)\end{array}$ & Significance \\
\hline Deafness & $\begin{array}{c}52 \\
(13.0)\end{array}$ & $\begin{array}{c}27 \\
(12.5)\end{array}$ & $\begin{array}{c}25 \\
(13.5)\end{array}$ & 0.553 \\
\hline Cataract & $\begin{array}{c}85 \\
(21.2)\end{array}$ & $\begin{array}{c}48 \\
(22.3)\end{array}$ & $\begin{array}{c}37 \\
(20)\end{array}$ & 0.571 \\
\hline Anaemia & $\begin{array}{c}150 \\
(37.5)\end{array}$ & $\begin{array}{c}60 \\
(27.9)\end{array}$ & $\begin{array}{c}90 \\
(48.6)\end{array}$ & $0.00^{*}$ \\
\hline Diabetes & $\begin{array}{c}59 \\
(14.7)\end{array}$ & $\begin{array}{c}25 \\
(11.6)\end{array}$ & $\begin{array}{c}34 \\
(18.4)\end{array}$ & $0.00^{*}$ \\
\hline Hypertension & $\begin{array}{c}167 \\
(41.7)\end{array}$ & $\begin{array}{c}92 \\
(42.7)\end{array}$ & $\begin{array}{c}75 \\
(40.5)\end{array}$ & 0.601 \\
\hline Osteoarthritis & $\begin{array}{c}210 \\
(52.5)\end{array}$ & $\begin{array}{c}97 \\
(45.1)\end{array}$ & $\begin{array}{l}113 \\
(61)\end{array}$ & $0.004^{*}$ \\
\hline Genitourinary & $\begin{array}{c}43 \\
(16.7)\end{array}$ & $\begin{array}{c}33 \\
(15.3)\end{array}$ & $\begin{array}{c}10 \\
(5.4)\end{array}$ & $0.017^{*}$ \\
\hline COPD & $\begin{array}{c}10 \\
(2.5)\end{array}$ & $\begin{array}{c}9 \\
(4.1)\end{array}$ & $\begin{array}{c}1 \\
(0.54)\end{array}$ & $0.019^{*}$ \\
\hline Asthma & $\begin{array}{c}18 \\
(4.5)\end{array}$ & $\begin{array}{c}9 \\
(4.1)\end{array}$ & $\begin{array}{c}9 \\
(4.9)\end{array}$ & 0.742 \\
\hline
\end{tabular}

Table 3 shows the association, of multi-morbidity with Age, Gender, place of residence, Marital Status, Literacy, socio-economic status. More of female participants $65 \%$ were suffering from multi-morbidity condition as compared to males $42.3 \%$, which was also found to be highly significant $(p<0.05)$.

The percentage of elderly living in urban (53.5\%), single (60\%) and belonging to age group $70-79$ years $(54.2 \%)$, were reported to have more multi-morbidity as compared to those living in rural area, married and elderly belonging to age group 60-69 years and $>80$ years, however the difference was not significant, whereas, more of literate elderly (63.4\%) 
Table 3: Associated factors with of levels of morbidity of study participants.

\begin{tabular}{|c|c|c|c|c|}
\hline $\begin{array}{c}\text { Socio- } \\
\text { demographic } \\
\text { variables }\end{array}$ & $\begin{array}{c}N=343 \\
(\%)\end{array}$ & $\begin{array}{c}\text { Single } \\
\text { Morbidity } \\
n=131 \\
\text { (\%) }\end{array}$ & $\begin{array}{c}\text { Multi } \\
\text { Morbidity } \\
n=212 \\
(\%)\end{array}$ & Significance \\
\hline \multicolumn{5}{|l|}{ Gender } \\
\hline Male & $\begin{array}{c}176 \\
(51.3)\end{array}$ & $\begin{array}{c}85 \\
(39.5)\end{array}$ & $\begin{array}{c}91 \\
(42.3)\end{array}$ & \multirow{2}{*}{$0.0007^{*}$} \\
\hline Female & $\begin{array}{c}167 \\
(48.7)\end{array}$ & $\begin{array}{c}46 \\
(24.9)\end{array}$ & $\begin{array}{c}121 \\
(65.4)\end{array}$ & \\
\hline \multicolumn{5}{|l|}{$\begin{array}{l}\text { Place of } \\
\text { residence }\end{array}$} \\
\hline Rural & $\begin{array}{c}173 \\
(50.4)\end{array}$ & $\begin{array}{c}68 \\
(34.0)\end{array}$ & $\begin{array}{c}105 \\
(52.5)\end{array}$ & \multirow{2}{*}{0.66} \\
\hline Urban & $\begin{array}{c}170 \\
(49.5)\end{array}$ & $\begin{array}{c}63 \\
(31.5)\end{array}$ & $\begin{array}{c}107 \\
(53.5)\end{array}$ & \\
\hline \multicolumn{5}{|c|}{ Age-Group (Years) } \\
\hline 60-69 & $\begin{array}{c}211 \\
(61.5)\end{array}$ & $\begin{array}{c}78 \\
(30.8)\end{array}$ & $\begin{array}{c}133 \\
(52.6)\end{array}$ & \multirow{3}{*}{0.423} \\
\hline $70-79$ & $\begin{array}{c}97 \\
(28.3)\end{array}$ & $\begin{array}{c}39 \\
(36.4)\end{array}$ & $\begin{array}{c}58 \\
(54.2)\end{array}$ & \\
\hline$>80$ & $\begin{array}{c}35 \\
(10.2)\end{array}$ & $\begin{array}{c}14 \\
(35.0)\end{array}$ & $\begin{array}{c}21 \\
(52.5)\end{array}$ & \\
\hline \multicolumn{5}{|l|}{$\begin{array}{l}\text { Education } \\
\text { Status }\end{array}$} \\
\hline Illiterate & $\begin{array}{c}157 \\
(45.8)\end{array}$ & $\begin{array}{c}46 \\
(26.8)\end{array}$ & $\begin{array}{c}111 \\
(63.4)\end{array}$ & \multirow{2}{*}{$0.001^{\star}$} \\
\hline literate & $186(54.2)$ & $85(37.8)$ & $\begin{array}{c}101 \\
(44.9)\end{array}$ & \\
\hline \multicolumn{5}{|l|}{ Marital Status } \\
\hline Single & $\begin{array}{c}88 \\
(25.6)\end{array}$ & $\begin{array}{c}28 \\
(28)\end{array}$ & $\begin{array}{c}60 \\
(60.0)\end{array}$ & \multirow{2}{*}{0.269} \\
\hline Married & $\begin{array}{c}255 \\
(74.4)\end{array}$ & $\begin{array}{c}103 \\
(34.4)\end{array}$ & $\begin{array}{c}152 \\
(50.7)\end{array}$ & \\
\hline \multicolumn{5}{|l|}{$\begin{array}{l}\text { Socioeconomic } \\
\text { Status }\end{array}$} \\
\hline Upper & $\begin{array}{c}97 \\
(28.3)\end{array}$ & $\begin{array}{c}45 \\
(35.7)\end{array}$ & $\begin{array}{c}52 \\
(41.3)\end{array}$ & \multirow{3}{*}{$0.003^{*}$} \\
\hline Middle & $\begin{array}{c}51 \\
(14.9)\end{array}$ & $\begin{array}{c}16 \\
(29.0)\end{array}$ & $\begin{array}{c}35 \\
(63.6)\end{array}$ & \\
\hline Lower & $\begin{array}{c}195 \\
(56.8)\end{array}$ & $\begin{array}{c}70 \\
(32.0)\end{array}$ & $\begin{array}{c}125 \\
(57.1)\end{array}$ & \\
\hline
\end{tabular}

were having multi-morbidity as compared to literate elderly (44.9\%), which was also found to be significant. In socio-economic class, the middle-class income group were having significantly more multi-morbidity (63.6\%), followed by $57 \%$ of lower class and $41.3 \%$ of upper class.

\section{DISCUSSION}

In our study the prevalence of morbidity among the elderly was found to be about $85.8 \%$ which is similar to study done in rural areas of Tamil Nadu and in Chandigarh which was around $86 \% .^{10,11}$ However higher rate of morbidity was also reported in a study conducted in Karnataka around $96 \%$ which is contrary to the present study. ${ }^{12}$ In the present study the most common morbidity reported was Osteoarthritis (52.5\%), which was similar to study, done. ${ }^{13-15}$ It was observed that significantly more of female $(61 \%)$ were suffering as compared to males (45\%), which could be attributed to the fact that hormonal withdrawal following post menopause can lead to degenerative and osteoporotic changes in female.

The prevalence of hypertension was around $42 \%$, which is similar to study done in Shimplapuri and Chandigarh respectively. ${ }^{16,17}$ In contrary the prevalence of hypertension among elderly was found to be around $22 \%$ in study. ${ }^{17,18} 28.1 \%$ in a study of which is almost half to our finding. In our study the prevalence of anemia was about $37.5 \%$, with more significantly among female $48.6 \%$ as compared to $27.9 \%$, which is similar to study. ${ }^{12}$ The prevalence of diabetes was around $14.75 \%$ similar to study, ${ }^{17,19} 11 \%$ and $12 \%$ respectively.

The multi-morbidity was reported to be significantly higher in Females in our study(65\%), which is comparable to study conducted in Bangladesh, ${ }^{13}$ in 2004 where around $65 \%$ female were having multi-morbidity, similarly in $2014^{20}$ in Nigeria has shown similar finding. This could be attributed to the fact that elderly women being more dependent, along with no financial securities and inaccessibility to health care could be the reason for suffering from more diseases. The multi-morbidity was also found to be significantly higher in illiterate elderly (63.4\%) as compared to literate elderly which is again similar to finding, ${ }^{13}$ as the illiterate population usually takes its diseases as part of natural ageing process and more reluctant to visit any kind of health facility for needful. The socio-economic class was also found to be statically significantly associated with multi-morbidity as more of middle-income group were having multi-morbidity (63.6\%), followed by Lower Income group (57.1\%) and Upper income group (41.3\%) which is similar to studies done. ${ }^{21}$

Multi-morbidity was also found to be higher among those who are single as loneliness can be associated with more of diseases, slightly more among urban elderly who could be due to more stress and isolated lifestyle and among elderly aged 70-79 years, however these finding were not statically important.

\section{CONCLUSION}

The present study was conducted on elderly aged more than 60 years residing in Allahabad district, where about half of them were suffering from multi-morbidity which was again more common among females, illiterate and middle socio-economic groups. The preventive programme and strategies should be focused on more frequent and periodic screening of elderly with special focus to elderly female, Health education and health service provision near the dwelling place through mobile health team and by peripheral workers.

\section{ACKNOWLEDGEMENT}

The authors would like to acknowledge all the study participants. We also grateful to interns in the Department of Community Medicine MLMNC Allahabad.

\section{CONFLICT OF INTEREST}

The authors declare that there are no conflicts of interest.

\section{ABBREVIATIONS}

COPD: Chronic obstructive pulmonary disease; SPSS: Statistical Package for the Social Sciences.

\section{REFERENCES}

1. http://www.who.int/healthinfo/survey/ageingdefnolder/en/. Philipov D, Goujon A, DiGivilio P. Agening Dynamic of a human-capital-specific popualtion. Demo- 
graphic Research. 2014;31(44):1311-36.

2. World Population Prospect: The 2002 Revision, Highlights. New York: United Nation Population Division. 2003.

3. Abolfotouh MA, Daffallah AA, Khan MY, Khattab MS, Abdulmoneim I. Psychosocial assessment of geriatric subjects in Abha City, Saudia Arabia. East Meditern Health J. 2001;7(3):481-91.

4. James K. India's demographic change: Opportunities and challenges. Science. 2011;333(6042):576-80.

5. United Nations. World Population Prospects. 2008. Revision: http://esa.un.org/ unpp.

6. Khanam M, Streatfield P, Kabir Z, et al. Prevalence and Pattern of Multimorbidity among elderly people in rural Bangladesh; A cross-sectional study. J Health Population Nutr. 2011;29(4):406-14

7. The world health report primary health care (Now More Than Ever). 2008. Avaliable at: http://www.who.int/whr/2008/en/ [cited at 26 March 2017]

8. Non-communicable diseases in the south-east Asia Region-profile. 2014. (www.searo.who.int/linkfiles/ncd_inforbase_diseasespecific.pdf).

9. Purty AJ, Bazroy J, Kar M, Vasudevan K, Veliath A, Panda P. Morbidity Pattern among the elderly population in the rural area of Tamil Nadu, India. Turk J Med Sci. 2006;36(1):45-50

10. Bhatia SPS, Swami HM, Thakur JS, Bhatia V. A study of health Problems and Ioneliness among elderly in Chandigarh. Indian Journal of Community Medicine. 2007;32(4):255-8.

11. Shahul H, Nanjesh K, Prasantha MN, Sachidananad K, Prasanna K. Morbidity pattern among the Elderly population ia a Rural Area of Dakshina Kannada, Karnataka - A Cross - sectional study. National Journal of Community Medicine. 2015;6(2):222-5.

12. Masuma AK, Peter KS, Zarina NK, Chengxuan Q, Christel C, Åke W. Preva- lence and Patterns of multi-morbidity among elderly People in Rural Bangladesh: A Cross-sectional Study. Journal of Health, Population and Nutrition. $2011 ; 29(4): 406-14$

13. Kavita B, Bipin P, Geeta K. Study of Health Profile of Residents of Geriatrics Home in Ahmedabad District. National Journal of Community Medicine. 2011;2(3):378-82.

14. Pallavi B, Jalandhar P. Socio-economic Inequalities in Prevalnce of Multi morbidity among Rural Elderly in Bargarh Dist. of Odisha (India). Plos One. 2014;9:1-10.

15. Kumar R, Ahlawat SK, Singh MM, Thakur JS. Time trends in prevalence of risk factors of cardiovascular diseases in Chandigarh. IAPSM, $3^{\text {rd }}$ Conference (NZ). Chandigarh. 2000.

16. Kajal S, Gupta SC, Kaushal SK, Mridul C. Morbidity profile of elderly: A cross sectional study of urban Agra. Indian Journal of Community Health. 2009;21(2). 2010;22(1):51-5

17. Vandana N, Fazila P, Abhiram B. A Study of Morbidity Profile among Geriatrics population in an Urban Area. Scholar Journal of Applied Medicine. 2015;3(3E):1365-9.

18. Swami HM, Bhatia V, Gupta AK, Bhatia SPS. An Epidemilogical Study of Obesity among elderly in Chandigarh. Indian J Community Med. 2005;30(1):1-5.

19. Abdulraheem IS, Amodu MO, Salami SK, Adegboye A, Atiregum FA, Tobin WC. Prevalance and Pattern of Multi-morbidity among Elderly people in Rural Nigeria: Implication for Health Care System, Research and Medical Education. Journal of Community Medicine and Health Care. 2017;2(3):1-13.

20. Akriti G, Sangeeta G, Anurag C, Jasneet SC, Pushapindra K. Pattern of Multimorbidity among Elderly in an Urban Area of North India. Journal of Evolution of Medical and Dental Sciences. 2016;5(19):936-41.

Cite this article : Verma V, Mishra N. A Study on Multi-morbidity among Geriatric Group in a District of Northern India: A Cross Sectional Study. Int J Med Public Health. 2019;9(4):137-40. 